\title{
Manufacturing Techniques of Ancient Metal Buddha Statues from Archaeological Sites in Bagan, Myanmar
}

\author{
Jae Sung Lee ${ }^{1}$, Yee Yee $\mathrm{Win}^{2}$, Bonnie Lee ${ }^{3}$, Jae Eun $\mathrm{Yu}^{4,}{ }^{*}$ \\ ${ }^{I}$ Cultural Heritage Conservation Science Center, National Research Institute of Cultural Heritage, Daejeon 34122, Korea \\ ${ }^{2}$ Bagan Archaeological Museum, Department of Archaeology, National Museum and Library, Myanmar \\ ${ }^{3}$ Planning \& Coordination Division, National Research Institute of Cultural Heritage, Daejeon 34122, Korea \\ ${ }^{4}$ Conservation Science Division, National Research Institute of Cultural Heritage, Daejeon 34122, Korea
}

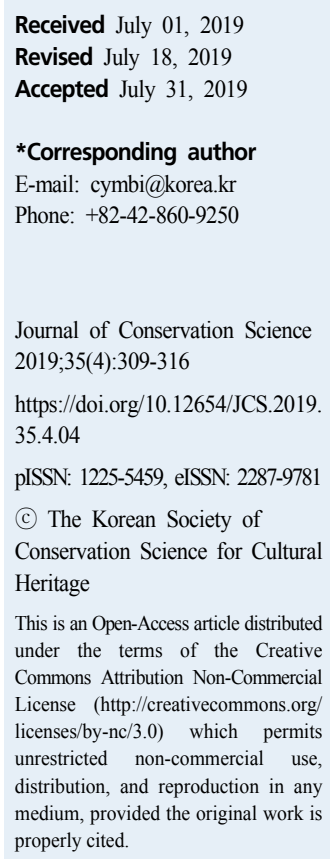

ABSTRACT This study intends to identify manufacturing techniques, including casting and alloy composition, of nine metal Buddha statues excavated from archaeological sites in Bagan, Myanmar. Two Buddha statues from Pyu city state $\left(2^{\text {nd }}\right.$ to $9^{\text {th }}$ century) contain $\mathrm{Cu}-\mathrm{Sn}$ alloy(including $<1 \mathrm{wt} \% \mathrm{Fe}$ ), with different relatively high percentages of $\operatorname{Sn}(16 \mathrm{wt} \%$ and $25 \mathrm{wt} \%)$ identified from each Buddha statue, and no $\mathrm{Pb}$ detected. Five Buddha statues from the Bagan dynasty contain various alloy ratios of $\mathrm{Cu}-\mathrm{Sn}$ (including $<1 \mathrm{wt} \% \mathrm{~Pb}$ ), $\mathrm{Cu}-\mathrm{Sn}-\mathrm{Pb}$, and $\mathrm{Cu}-\mathrm{Sn}-\mathrm{Zn}-\mathrm{Pb}$. All Buddha statues appear to be fabricated by casting, as there is no evidence of other heat treatments. The silver Buddha statue manufactured in the $18^{\text {th }}$ century includes $>1 \%$ Cu besides silver with no additional metallic components identified. The bronze Buddha statue manufactured in the Konbaung dynasty( $18^{\text {th }}$ century) is of $\mathrm{Cu}-\mathrm{Sn}-\mathrm{Pb}$ alloy. The Buddha statues of Pyu was alloy of $\mathrm{Cu}-\mathrm{Sn}$ without $\mathrm{Pb}$ including ahigh percentage of The Buddha statues of both the Bagan and Konbaung dynasties are comprised of ternary $\mathrm{Cu}-\mathrm{Sn}-\mathrm{Pb}$ alloys, with a heterogeneous distribution of lead and tin. Some of Buddha statues of the Bagan dynasty have similar alloy ratios as those of Pyu, suggesting that similar manufacturing techniques were used.

Key Words Myanmar, Bagan, Ancient metal Buddha statue, Manufacturing technique

\section{INTRODUCTION}

The Bagan dynasty(1044-1287 AD) was the first unified state in Myanmar with a great legacy in the history of Myanmar. Bagan is a region located on the left bank of the Ayayarwady River(Aung-Thwin, 1985). The traditional idiom(Hle-WinyoThan-Ta-Nyan-Nyan-Bagan-Phayabaung) states that there were 4446 pagodas in Bagan, but only 3312 monuments remain today. Most of the Buddhist monuments today were constructed during the $11^{\text {th }}$ to $13^{\text {th }}$ centuries, but the history of Bagan starts in the early $2^{\text {nd }}$ century with King Thamudarit.
He was a nephew of the King of Pyu named Thupyinnya Nagra Seinda. Fifty kings in total ruled Bagan throughout its history. The city wall of Bagan today was built by the $34^{\text {th }}$ king, Pyinbya. Theravada Buddhism of Myanmar began to flourish under King Anawrahta, as demonstrated by the numerous pagodas and temples covering approximately 42 square kilometers(Aung, 1967). After the fall of Bagan, the Pinya, Ava, and Konbaung dynasties followed. These dynasties also protected and repaired the old pagodas built by their ancestors as a meritorious deed. The region of Bagan has played a central role in the practice of Buddhism in Myanmar 
over centuries; therefore, there are a variety of religious cultural heritage sites and artifacts preserved. Buddha statues from various periods(of different sizes, shapes, and materials) are still worshipped to this day. There are currently few Buddha statues that were fabricated in the most splendid period $\left(11^{\text {th }}\right.$ to $13^{\text {th }}$ century) of the Bagan region. However, the process of manufacturing metal Buddha statues can be achieved by smelting, alloying, and casting, making it is possible to investigate manufacturing techniques at that time.

This study intends to identify manufacturing techniques by analyzing nine bronze Buddha statues which were excavated from archaeological sites in Bagan, Myanmar. In addition, to understand features of Buddha statues from the Bagan dynasty, a comparative study was carried out with statues of another period.

\section{METHODOLOGIES}

\subsection{Sampling}

Nine bronze Buddha statues from the Bagan Archaeological Museum in Myanmar were analyzed(National Research Institute of Cultural Heritage, 2017). To limit damage to the statues, minimum size fragments were prepared for analysis. For sampling objects, artifacts from the Bagan dynasty $\left(11^{\text {th }}\right.$ to $13^{\text {th }}$ century) and artifacts from the Pyu city $\operatorname{states}\left(2^{\text {nd }}\right.$ to $9^{\text {th }}$ century) and Konbaung dynasty( $18^{\text {th }}$ century) were selected for comparison with samples from the Bagan dynasty.

\subsection{Sample preparation}

Samples for analysis were mounted in epoxy resin and the sample surfaces were polished smooth using a polishing machine
(Struers Tegramin-20, DNK). Polishing was carried out gradually with polish papers from serial number \#220 to \#4000 in ascending order of granularity, finishing with a $1 \mu \mathrm{m}$-diamond suspension. After polishing, the surfaces of the samples were etched in a solution of ethyl alcohol $(120 \mathrm{~mL})$, hydrochloric $\operatorname{acid}(30 \mathrm{~mL})$, and iron chloride(III)(10 g).

\subsection{Method of analysis}

The microstructure of samples was observed using a metallurgical microscope(Leica DMRBE, DEU) at low and high magnification. Surfaces before and after etching were identified and their images were photographed using a professional digital camera. Analysis of components and observation of features in the microstructure were conducted with scanning electron microscopy-energy dispersive spectroscopy (SEM-EDS)(JEOL JSM-IT300, JPN/ Oxford, GBR). EDS analysis was performed at a working distance of $10 \mathrm{~mm}$ after fixing samples with carbon tape. Sample surfaces were carbon-coated to minimize errors in analyzing bronze samples by SEM-EDS.

\section{RESULTS OF ANALYSIS}

\subsection{Buddha statues from Pyu city states} ( $2^{\text {nd }}$ to $9^{\text {th }}$ century)

\subsubsection{Bronze Buddha statue No. 1}

The bronze Buddha statue No. 1 has a severely abraded face from corrosion and a broken right knee. The sample was taken from the pedestal and analyzed(Figure 1a). Figure $1 \mathrm{~b}$ is the SEM micrograph of the microstructure of the sample. It shows the a phase, which forms the background, and the white
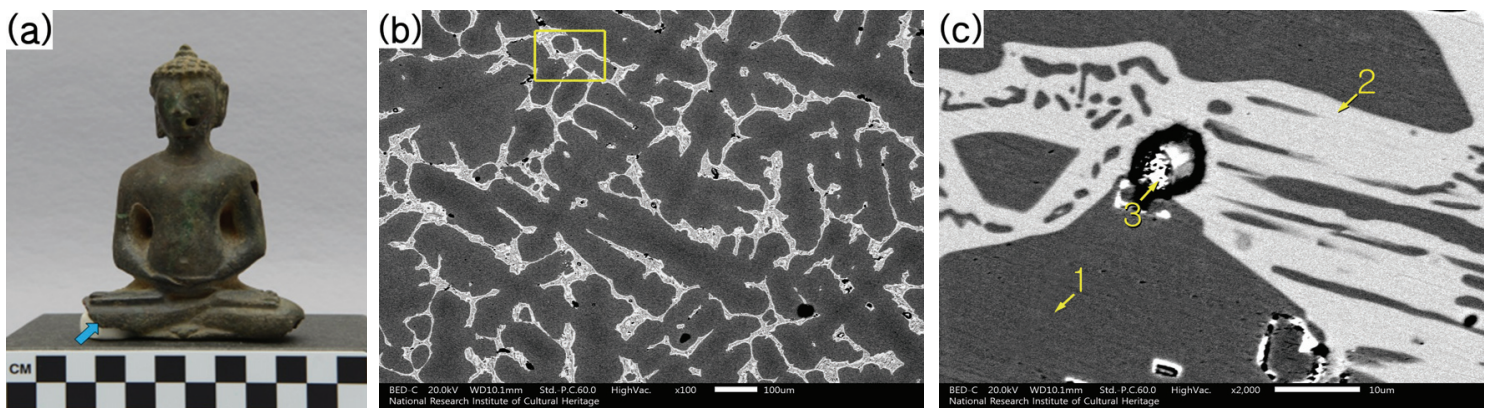

Figure 1. Microstructure of bronze Buddha statue No.1. (a) Photo of the statue's appearance with blue arrow pointing to sample region, (b) Low magnification SEM micrograph and (c) High magnified SEM micrograph of figure $1 \mathrm{~b}$. 
Table 1. SEM-EDS analysis of bronze Buddha statue No. 1

\begin{tabular}{|c|c|c|c|c|c|c|c|c|c|}
\hline \multirow{2}{*}{ Analysis area } & \multicolumn{9}{|c|}{ Components (wt\%) } \\
\hline & $\mathrm{Cu}$ & $\mathrm{Sn}$ & $\mathrm{Zn}$ & $\mathrm{Pb}$ & $\mathrm{S}$ & $\mathrm{Fe}$ & $\mathrm{Na}$ & $\mathrm{O}$ & Total \\
\hline Entire area & 83.75 & 16.25 & - & - & - & - & - & - & 100.00 \\
\hline Point $1(\alpha)$ & 85.37 & 14.63 & - & - & - & - & - & - & 100.00 \\
\hline Point $2(\delta)$ & 67.37 & 32.63 & - & - & - & - & - & - & 100.00 \\
\hline Point $3(\mathrm{~Pb})$ & 83.96 & 10.94 & - & 5.10 & - & - & - & - & 100.00 \\
\hline
\end{tabular}

$\delta$ phase. Only a trace of lead is found, so it does not affect the general composition of the sample. The entire composition of the alloyed sample is comprised of $83.75 \mathrm{wt} \%$ copper and $16.25 \mathrm{wt} \%$ tin.

Figure $1 \mathrm{c}$ is the magnified micrograph of the formed a phase, $\delta$ phase, and lead particles. Point 1 indicates the a phase, which consists of $85.37 \mathrm{wt} \%$ copper and $14.63 \mathrm{wt} \%$ tin. Point 2 is the $\delta$ phase and it contains $67.37 \mathrm{wt} \%$ copper and 32.63 wt $\%$ tin. Point 3 shows the lead particles that are located among $\delta$ phases in trace amounts, estimated as $\sim 5.10 \mathrm{wt} \%$ lead, which affects the microstructure of the surrounding components(Table 1).

\subsubsection{Comparison of Buddha statues from Pyu city states}

Two Buddha statues from Pyu city states $\left(2^{\text {nd }}\right.$ to $9^{\text {th }}$ century) were analyzed for the components of the $\mathrm{Cu}-\mathrm{Sn}$ alloy (including $\mathrm{Fe}$ under $1 \mathrm{wt} \%$ ), and the different percentages (16.25 wt $\%$ and $25.12 \mathrm{wt} \%$ ) of Sn were identified from each Buddha statue. The microstructure is composed of an $a+\delta$ phase with no indication of heat treatment. $\mathrm{S}$ and Fe were detected in slag inclusions(Table 2), which suggests that the copper ore supplied for the statue might be chalcocite or copper pyrite(Park and Yu, 2004).

\subsection{Buddha statues from the Bagan dynasty} $\left(11^{\text {th }}\right.$ to $13^{\text {th }}$ century)

\subsubsection{Gilt bronze Buddha statue No. 3}

The surface of the gilt bronze Buddha statue was abraded due to corrosion, but a gilt layer still remains on some parts of the shoulder and pedestal surfaces. The sample was taken from the pedestal and analyzed(Figure $2 \mathrm{a}$ ). Figure $2 \mathrm{~b}$ is the optical microscopic photo showing the microstructure of the gilt bronze Buddha statue. It shows corrosion layers formed along grain boundaries, with lead particles appearing black and evenly distributed. The entire sample is an alloy of $83.97 \mathrm{wt} \%$ copper, $5.67 \mathrm{wt} \%$ tin, $5.37 \mathrm{wt} \%$ zinc, and $4.98 \mathrm{wt} \%$ lead.

The SEM micrograph of the un-corroded part of the sample is magnified(Figure 2c). It contains white lead particles and very fine grey inclusions. Non-metallic inclusions and elliptical lead particles can be observed more accurately in Figure 2c, and these were further analyzed to identify the compositional difference of these structures using EDS. The analysis shows that a similar amount of tin and zinc, as well as a significant amount of copper are found at Point 1 , and that mainly lead and the trace of lead are found at Point 2. Point 3 is the result of inclusions, including sulfur, zinc, iron, sodium, and copper, suggesting that the metal used for fabricating this Buddha

Table 2. Analysis of bronze Buddha statues from Pyu city states(National Research Institute of Cultural Heritage, 2017)

\begin{tabular}{|c|c|c|c|c|c|c|c|c|}
\hline \multirow{2}{*}{\multicolumn{2}{|c|}{ No. Artifact }} & \multirow{2}{*}{ Period } & \multirow{2}{*}{ Material } & \multirow{2}{*}{$\begin{array}{l}\text { Measurements } \\
\qquad(\mathrm{cm})\end{array}$} & \multicolumn{2}{|c|}{ Microstructure } & \multirow{2}{*}{$\begin{array}{l}\text { Main elements } \\
\text { components } \\
\text { (wt } \%)\end{array}$} & \multirow{2}{*}{$\begin{array}{l}\text { Characteristic \& } \\
\text { manufacture }\end{array}$} \\
\hline & & & & & Optics & SEM & & \\
\hline 1 & $\overrightarrow{H H}$ & Pyu & Bronze & $\begin{array}{l}\text { Height: } 11.3 \\
\text { Width: } 7.8\end{array}$ & & & $\begin{array}{l}\mathrm{Cu} 83.75 \\
\mathrm{Sn} 16.25\end{array}$ & $\begin{array}{l}\text { - Copper, } \\
\text { Tin alloy } \\
\text { - Cast } \\
\text { - } \alpha, \delta \text { phase }\end{array}$ \\
\hline 2 & & Pyu & Bronze & $\begin{array}{l}\text { Height: } 6.5 \\
\text { Width: } 3.7\end{array}$ & & & $\begin{array}{lc}\mathrm{Cu} & 74.145 \\
\mathrm{Sn} & 25.12 \\
\mathrm{Fe} & 0.59 \\
\mathrm{~S} & 0.15\end{array}$ & $\begin{array}{l}\text { - Copper, } \\
\text { Tin alloy } \\
\text { - Sulfur inclusion } \\
\text { - Cast } \\
\text { - } \alpha, \delta \text { phase }\end{array}$ \\
\hline
\end{tabular}



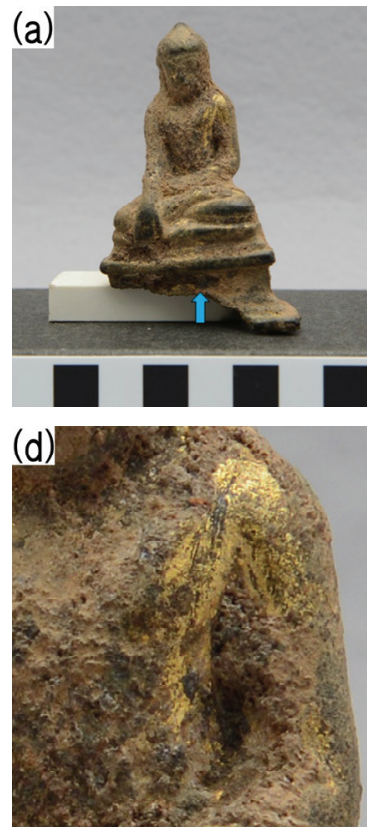

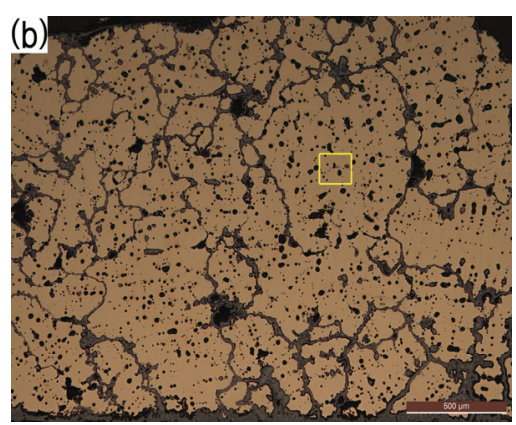

(e)

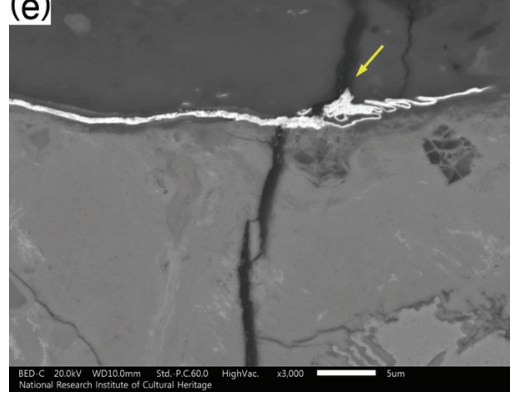

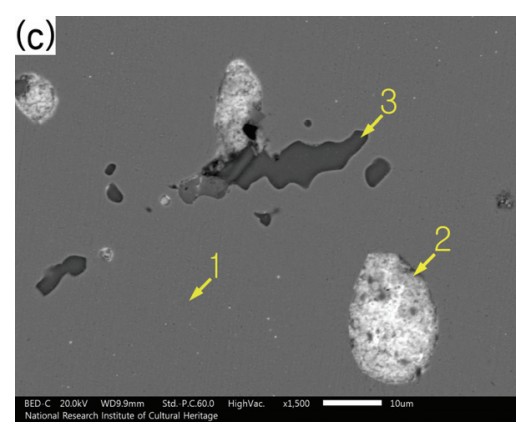

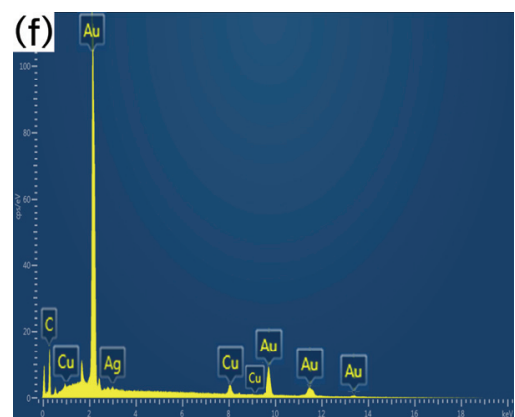

Figure 2. Microstructure of gilt bronze Buddha statue No.3. (a) Photo of the statue's appearance with blue arrow pointing to sample region, (b) Low magnification optical micrograph, (c) High magnified SEM micrograph of figure 2b, (d) Detail of gilt on surface of statue, (e) SEM micrograph of the gilt layer and (f) EDS spectrum of the gilt layer.

Table 3. SEM-EDS analysis of gilt bronze Buddha statue No. 3

\begin{tabular}{lccccccccccc}
\hline \multirow{2}{*}{ Analysis area } & \multicolumn{10}{c}{ Components (wt\%) } \\
\cline { 2 - 12 } & $\mathrm{Cu}$ & $\mathrm{Sn}$ & $\mathrm{Zn}$ & $\mathrm{Pb}$ & $\mathrm{S}$ & $\mathrm{Fe}$ & $\mathrm{Na}$ & $\mathrm{Au}$ & $\mathrm{Ag}$ & $\mathrm{O}$ & Total \\
\hline Entire area & 83.97 & 5.67 & 5.37 & 4.98 & - & - & - & - & - & - & 100.00 \\
\hline Point 1 $(\alpha)$ & 88.19 & 5.56 & 5.62 & - & - & 0.63 & - & - & - & - & 100.00 \\
Point 2 $(\mathrm{Pb})$ & 2.92 & - & - & 87.00 & - & - & - & - & - & 10.08 & 100.00 \\
Point 3 & 2.06 & - & 54.41 & - & 33.51 & 1.07 & 8.95 & - & - & - & 100.00 \\
Gilt layer & 5.55 & - & - & - & - & - & - & 90.87 & 1.50 & 2.08 & 100.00 \\
\hline
\end{tabular}

statue was sulfide(Table 3). Gold leaf was applied for gilding (Figure $2 \mathrm{~d}$ and $2 \mathrm{e}$ ), and no mercury was detected in the gilt layer(Figure 2f), indicating that amalgam plating was not applied(Lee and Jeon, 2017).

\subsubsection{Bronze Buddha statue No. 7}

The bronze Buddha statue No. 7 was extremely degraded; the head, both hands, and right knee are missing. Due to the corrosion, the surface of the statue was very abraded. The sample for analysis was removed from the pedestal(Figure 3a). Figure $3 \mathrm{~b}$ is the microscopic photo showing the microstructure, including dendritic a phases and $\delta$ phases. The components are mainly copper(75.85 wt $\%$ ) with a large amount of tin
(22.76 wt $\%$ ), and $<1 \mathrm{wt} \%$ each of lead, sulfur, and iron. The small spots on Figure $3 \mathrm{~b}$ are inclusions that were not removed perfectly during the smelting process. Figure $3 \mathrm{c}$ is the magnified micrograph of the lower part of Fig $3 \mathrm{~b}$ using SEM, indicating the presence of four different phases, which were further analyzed with $\operatorname{EDS}($ Table 4). Point 1, which is the a phase, contains $84.59 \mathrm{wt} \%$ copper and $15.01 \mathrm{wt} \%$ tin. Mainly copper and $\sim 33.73 \mathrm{wt} \%$ tin were detected at Point 2 (the $\delta$ phase). Point 3 is a trace of lead alloy in the microstructure, which is composed of $77.87 \mathrm{wt} \%$ lead, $\sim 4.90$ wt $\%$ copper, and $5.23 \mathrm{wt} \%$ bismuth. The large amount of sulfur and iron at Point 4 indicates that the inclusion is sulfide(Table 4). 

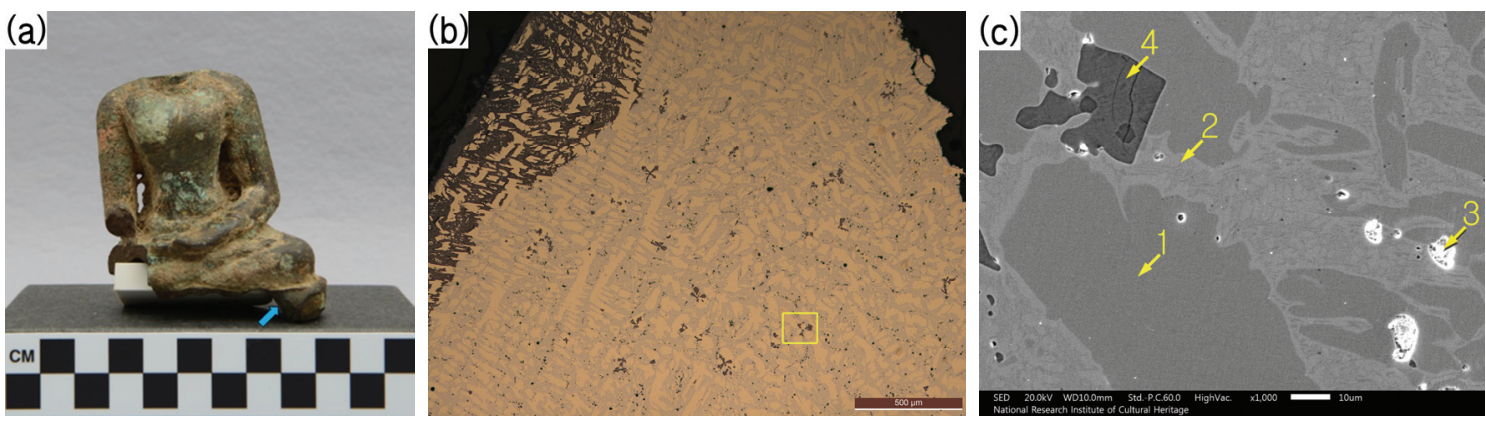

Figure 3. Microstructure of bronze Buddha statue No. 7. (a) Photo of the statue's appearance with blue arrow pointing to sample region, (b) Low magnification optical micrograph and (c) High magnified SEM micrograph of figure $3 b$.

Table 4. SEM-EDS analysis of bronze Buddha statue No. 7

\begin{tabular}{lrccccccccc}
\hline \multirow{2}{*}{ Analysis area } & \multicolumn{10}{c}{ Components $(\mathrm{wt} \%)$} \\
\cline { 2 - 12 } & $\mathrm{Cu}$ & $\mathrm{Sn}$ & $\mathrm{Sb}$ & $\mathrm{Pb}$ & $\mathrm{S}$ & $\mathrm{Fe}$ & $\mathrm{Ag}$ & $\mathrm{Bi}$ & $\mathrm{O}$ & Total \\
\hline Entire area & 75.85 & 22.76 & - & 0.74 & 0.25 & 0.39 & - & - & - & 100.00 \\
\hline Point 1 $(\alpha)$ & 84.59 & 15.01 & - & - & - & 0.40 & - & - & - & 100.00 \\
Point 2 $(\delta)$ & 66.27 & 33.73 & - & - & - & - & - & - & - & 100.00 \\
Point 3 $(\mathrm{Pb})$ & 4.90 & 0.56 & - & 77.87 & - & - & - & 5.23 & 11.43 & 100.00 \\
Point 4 & 59.39 & - & - & - & 27.85 & 12.76 & - & - & - & 100.00 \\
\hline
\end{tabular}

Five Buddha statues from the Bagan dynasty were analyzed based on the various ratios of metals contained in the alloys of $\mathrm{Cu}-\mathrm{Sn}$ (including $<1 \mathrm{wt} \% \mathrm{~Pb}$ ), $\mathrm{Cu}-\mathrm{Sn}-\mathrm{Pb}$, and $\mathrm{Cu}-\mathrm{Sn}-\mathrm{Zn}-\mathrm{Pb}$ (Table 5). The range of $\mathrm{Sn}$ varies from $5 \mathrm{wt} \%$ to $22 \mathrm{wt} \%$ among the five statues. There is no indication of heat treatment after casting in the $a+\delta$ phase of the microstructures, except the alloy of $\mathrm{Cu}-\mathrm{Sn}-\mathrm{Zn}-\mathrm{Pb}$ with a low content of $\mathrm{Sn}$. The most distinguishing feature is whether the sample contains lead and zinc or not. The difference of $\mathrm{Pb}$ content in the Buddha statues is between $1 \mathrm{wt} \%$ and $9 \mathrm{wt} \%$. Zinc is present in $5 \mathrm{wt} \%$, which is relatively low, but considering the fact that bronze coins containing $14 \mathrm{wt} \% \mathrm{Zn}$ were used in the same period, there is the possibility that $\mathrm{Zn}$ was intentionally added(National Research Institute of Cultural Heritage, 2017). Sulfur inclusion suggests that the supplied copper ore might be chalcocite or copper pyrite(Table 5).

\subsection{Buddha statues from the Konbaung dynasty ( $18^{\text {th }}$ century)}

\subsubsection{Bronze Buddha statue No. 8}

The Buddha statue and pedestal were cast as a whole, in which part of the pedestal has fallen apart, but its overall condition is quite sound. The sample was taken from the pedestal and analyzed(Figure 4a) by $\operatorname{SEM}($ Figure $4 b$ ), which shows the microstructure including a $\delta$ phase formed in the background dendritic a phase. Lead particles in irregular sizes and shapes were solidified, with the overall components being $80.35 \mathrm{wt} \% \mathrm{Cu}, 10.57 \mathrm{wt} \% \mathrm{Sn}$, and $9.08 \mathrm{wt} \% \mathrm{~Pb}$. Figure $4 \mathrm{c}$ is the magnified micrograph of the upper part of Figure $4 \mathrm{~b}$ using SEM, displaying four types of phases in the microstructure that were further analyzed by EDS(Table 6). Point 1 represents the a phase consisting mainly of $\mathrm{Cu}$ and $13.35 \mathrm{wt} \% \mathrm{Sn}$, Point 2 is the $\delta$ phase containing $\sim 31.77 \mathrm{wt} \% \mathrm{Sn}$, Point 3 is the $\mathrm{Pb}$ particle containing $10 \mathrm{wt} \%$ bismuth, and Point 4 is the inclusion consisting of $22.93 \mathrm{wt} \% \mathrm{~S}, 74.82 \mathrm{wt} \% \mathrm{Cu}$, and $2.25 \mathrm{wt} \% \mathrm{Fe}$.

A bronze Buddha statue and a silver Buddha statue belonging to the Kongbaung dynasty were analyzed(Table 7). The bronze Buddha statue was fabricated by casting with an alloy of $\mathrm{Cu}-\mathrm{Sn}-\mathrm{Pb}$ without subsequent heat treatment. Sulfur and iron were identified in non-metallic inclusions arising from sulfide that was not completely eliminated and remained in the microstructure during the process of smelting. The silver 
Table 5. Analysis of bronze Buddha statues from the Bagan dynasty(National Research Institute of Cultural Heritage, 2017)

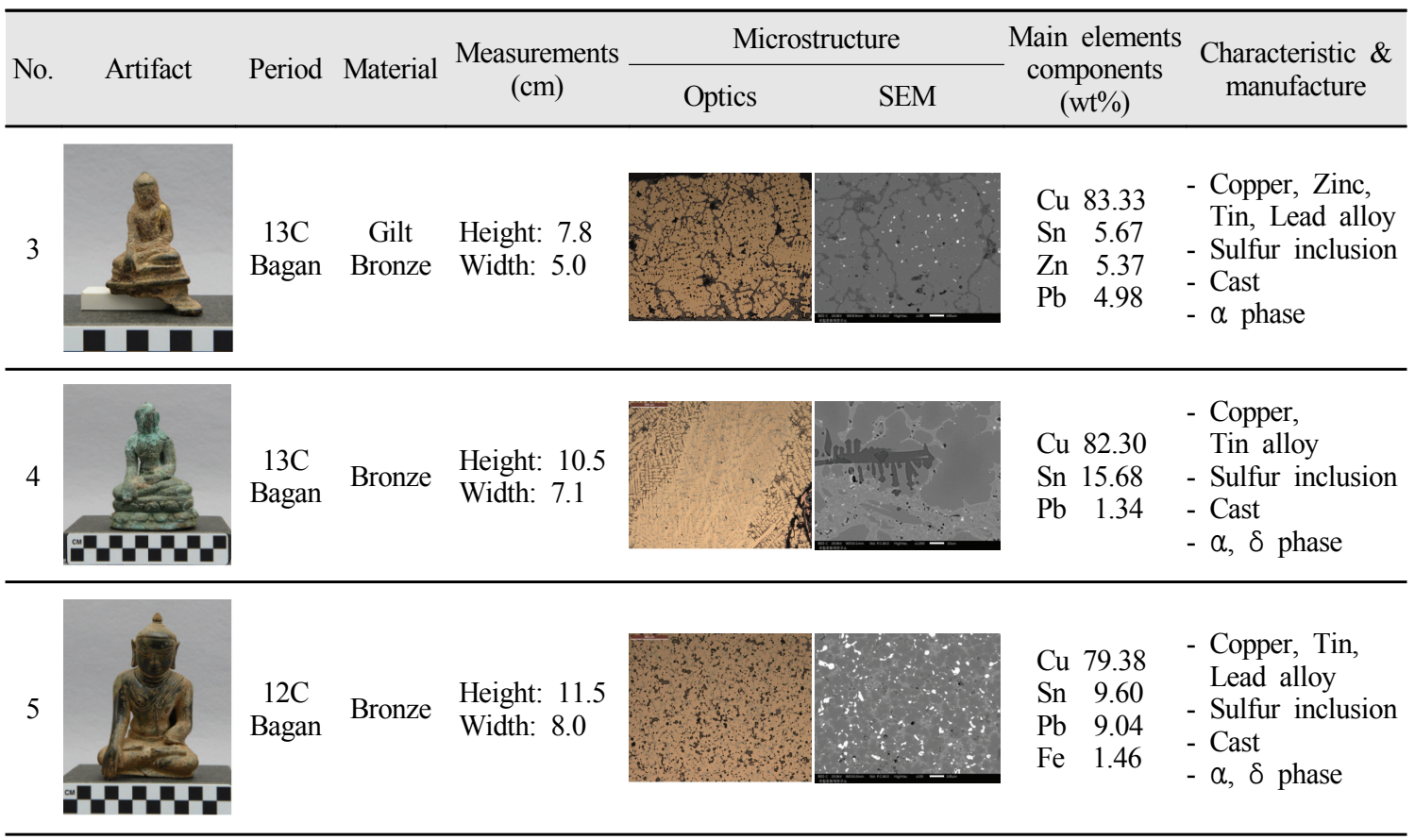

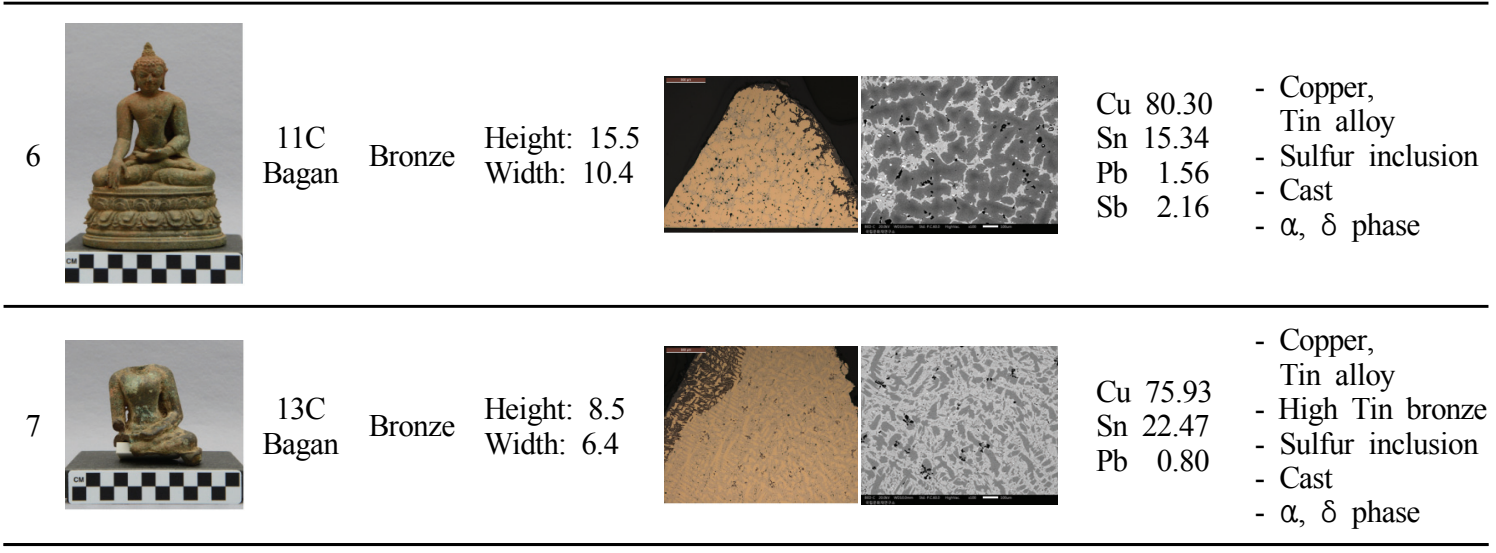
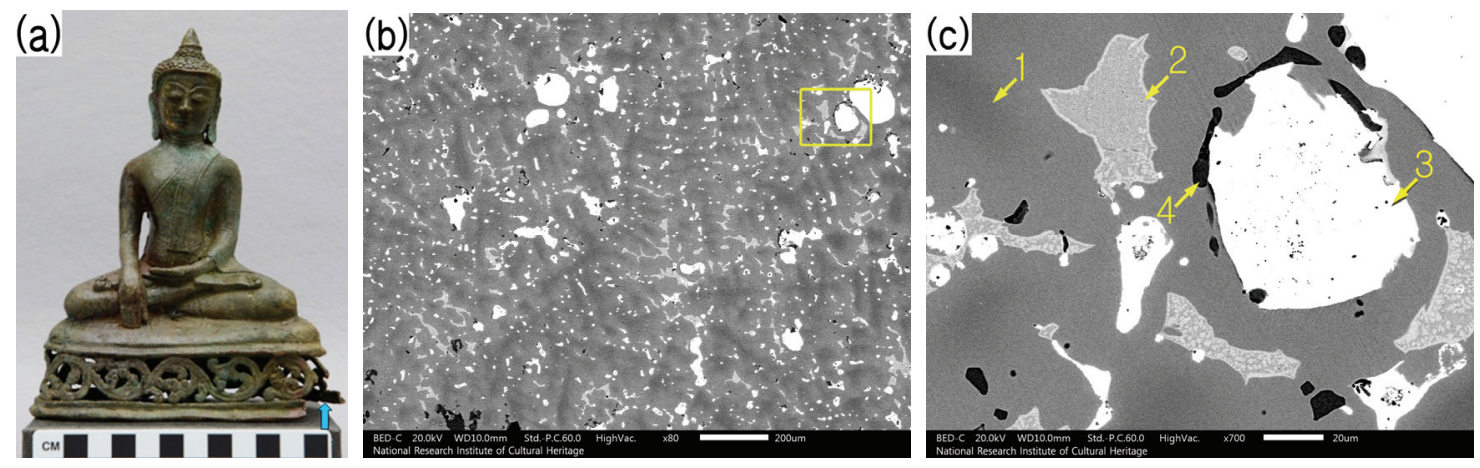

Figure 4. Microstructure of bronze Buddha statue No. 8. (a) Photo of the statue's appearance with blue arrow pointing to sample region, (b) Low magnification SEM micrograph and (c) High magnified SEM micrograph of figure 4b. 
Table 6. SEM-EDS analysis of bronze Buddha statue No. 8

\begin{tabular}{lcccccccccc}
\hline \multirow{2}{*}{ Analysis area } & \multicolumn{10}{c}{ Components (wt\%) } \\
\cline { 2 - 11 } & $\mathrm{Cu}$ & $\mathrm{Sn}$ & $\mathrm{Sb}$ & $\mathrm{Pb}$ & $\mathrm{S}$ & $\mathrm{Fe}$ & $\mathrm{Ag}$ & $\mathrm{Bi}$ & $\mathrm{O}$ & Total \\
\hline Entire area & 80.35 & 10.57 & - & 9.08 & - & - & - & - & - & 100.00 \\
\hline Point 1 $(\alpha)$ & 86.65 & 13.35 & - & - & - & - & - & - & - & 100.00 \\
Point 2 $(\delta)$ & 68.23 & 31.77 & - & - & - & - & - & - & - & 100.00 \\
Point 3 $(\mathrm{Pb})$ & 0.62 & - & - & 84.90 & - & - & - & 9.90 & - & 100.00 \\
Point 4 & 74.82 & - & - & - & 22.93 & 2.25 & - & - & - & 100.00 \\
\hline
\end{tabular}

Table 7. Analysis of metal Buddha statues from the Konbaung dynasty(National Research Institute of Cultural Heritage, 2017)

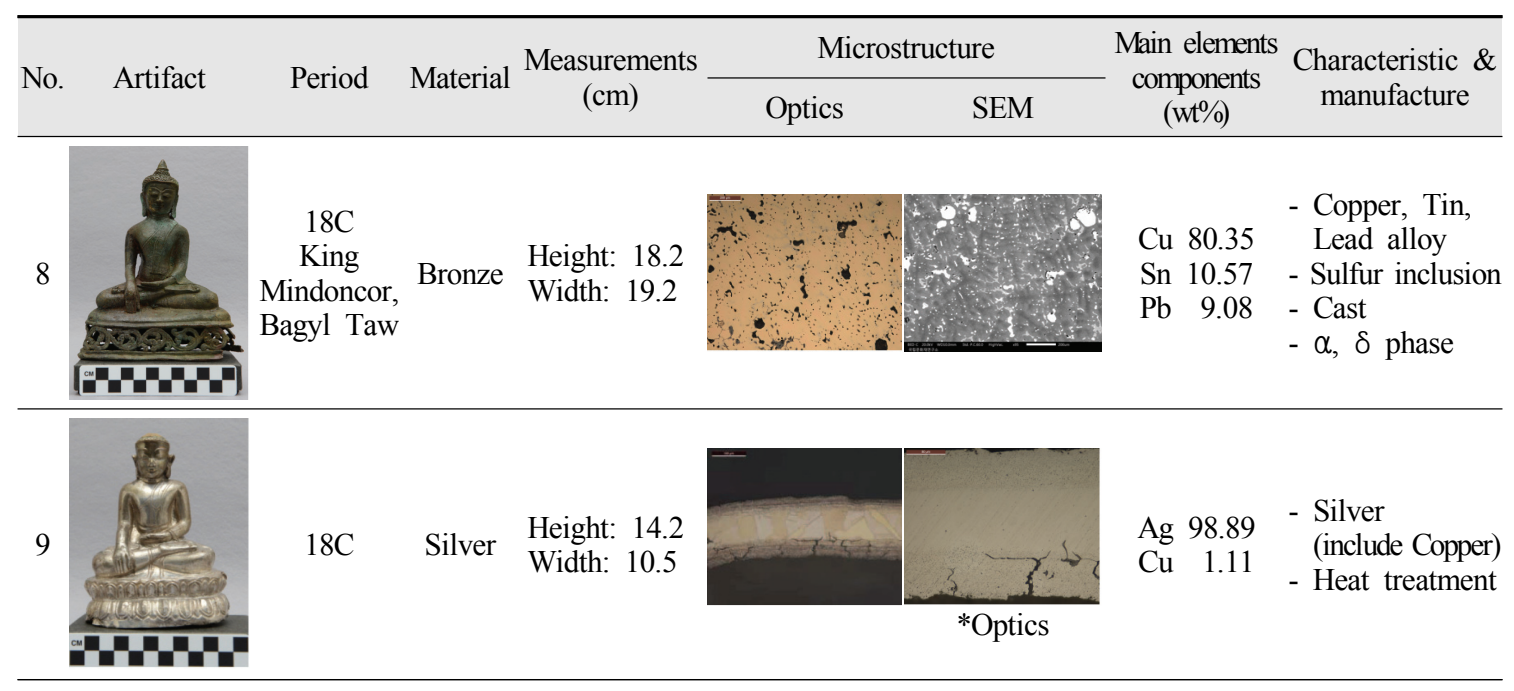

Buddha statue that was manufactured in the $18^{\text {th }}$ century includees $>1 \% \mathrm{Cu}$ in addition to $\mathrm{Ag}$ without other metallic elements present(Table 7). The porous oxidized layer that formed on both surfaces of silver plates is observed, suggesting that heat treatments at high temperature were used because such porous oxidized layers are formed when $\mathrm{Ag}$ is heated over $400^{\circ} \mathrm{C}(\mathrm{Ryu}$ and $\mathrm{Kim}, 2011)$.

\section{SUMMARY AND CONCLUSIONS}

The Buddha statues are classified into four types(1) $\mathrm{Cu}-\mathrm{Sn}$, (2) $\mathrm{Cu}-\mathrm{Sn}-\mathrm{Pb}$, (3) $\mathrm{Cu}-\mathrm{Sn}-\mathrm{Zn}-\mathrm{Pb}$, (4) Ag). In terms of the range for analysis, a bronze Buddha statue from the Pyu period before the $9^{\text {th }}$ century to those of the Bangan and Konbaung periods $\left(11^{\text {th }}\right.$ to $13^{\text {th }}$ and $18^{\text {th }}$ century, respectively) were extensively analyzed. Two Buddha statues from the Pyu period fabricated from $\mathrm{Cu}-\mathrm{Sn}$ alloys contain $16.25 \mathrm{wt} \%$ and $25.12 \mathrm{wt} \% \mathrm{Sn}$.
Typical microstructures $(\alpha+\delta)$ of casting were identified, along with no additional heat treatment or tempering after shaping by casting. The $\mathrm{Cu}-\mathrm{Sn}$ alloy for fabricating the Buddha statues did not include any significant amount of $\mathrm{Pb}$, especially for Buddha statue No. 2 from the Pyu period containing $>25 \mathrm{wt} \% \mathrm{Sn}$, which is one of the defining features of the period.

The five Buddha statues of the Bagan period were analyzed and shown various alloy compositions such as (1) $\mathrm{Cu}-\mathrm{Sn}$, (2) $\mathrm{Cu}-\mathrm{Sn}-\mathrm{Pb}$, (3) $\mathrm{Cu}-\mathrm{Sn}-\mathrm{Zn}-\mathrm{Pb}$. The bronze Buddha statue No.7 fabricated from an alloy of $\mathrm{Cu}$ and $\mathrm{Sn}$ included 22.47 $\mathrm{wt} \% \mathrm{Sn}$, with $<1 \mathrm{wt} \% \mathrm{~Pb}$ that was not intentionally added. The typical microstructures $(\alpha$ and $a+\delta)$ of casting were identified and there was no additional heat treatment and tempering after shaping by casting. The manufacturing technique of alloying $\mathrm{Cu}$ with large amounts of $\mathrm{Sn}$ in this period has something in common with the Pyu period. In the case of the 
$\mathrm{Cu}-\mathrm{Sn}-\mathrm{Pb}$ alloy, a trace of $\mathrm{Fe}$ is detected in the bronze Buddha statues, which most likely is present in the alloy from use of copper ore(Jeon et al., 2013). The gilt bronze Buddha statue has an alloy of $\mathrm{Cu}-\mathrm{Sn}-\mathrm{Zn}-\mathrm{Pb}$ with $\mathrm{Zn}$ intentionally included. It was gilded with very thin and uniform gold leaf $<1 \mu \mathrm{m}$ thick using a gold-plating technique with gold leaf applied on the surface, consisting of $97 \%$ pure gold without any $\mathrm{Hg}$ detected. The difference between the compositions of the bronze Buddha statues and the gilt-bronze Buddha statue is related to the fabrication technique by casting.

The Buddha statues of the Konbaung period were fabricated with $\mathrm{Cu}-\mathrm{Sn}-\mathrm{Pb}$ alloys exhibiting typical microstructures $(\mathrm{a}+\delta)$ produced from casting and with no additional heat treatment performed. The particles of lead contained $\sim 10 \mathrm{wt} \% \mathrm{Bi}$, which was the only component detected besides the major component, lead, suggesting that $\mathrm{Bi}$ was present in the lead ore provided as the raw material. This was identified in some bronze Buddha statues of the Bagan period as well. The silver Buddha statue includes a trace of $\mathrm{Cu}$ of $\sim 1 \mathrm{wt} \%$ besides silver, and nothing else. The non-metallic inclusion contains sulfur, which indicates with high possibility that the copper provided as the raw material was extracted from copper ores containing sulfur, such as copper pyrite or chalcocite.

Each defining feature of Buddha statues is summarized in the following. The Buddha statue of Pyu contained an alloy of $\mathrm{Cu}-\mathrm{Sn}$ with a high percentage of $\mathrm{Sn}$ and without $\mathrm{Pb}$. It is believed that more than $25 \%$ of Sn content in this case was for the purpose of color on the surface of the Buddha statue (Lee and Park, 2014). The Buddha statues of the Bagan and Konbaung dynasties contain ternary alloys of $\mathrm{Cu}-\mathrm{Sn}-\mathrm{Pb}$, with a heterogeneous distribution of lead and tin. Similar alloy ratios were identified in some of the Buddha statues of the Bagan dynasty with those of Pyu, leading us to conclude that similar manufacturing techniques were used.

\section{ACKNOWLEDGEMENTS}

This study was funded by the Cultural Heritage R\&D Project of the National Research Institute of Cultural Heritage, Cultural Heritage Administration and we are deeply grateful for their administrative and financial support.

\section{REFERENCES}

Aung, M.H., 1967, A history of Burma. Columbia University Press, New York.

Aung-Thwin, M., 1985, Pagan: The origins of modern Burma. Honolulu: University of Hawaii Press, Hawaii.

Jeon, I.H., Lee, J.S. and Park, J.S., 2013, Technological diversities observed in bronze objects of the late Goryo period - Case study on the bronze bowls excavated from the burial complex at Deobu-gol in Goyang. Korean Journal of Cultural Heritage Studies, 46(1), 208-227. (in Korean with English abstract)

Lee, J.S. and Jeon, I.H., 2017, Study of casting and plating methods used in production of gilded bronze wind-chime excavated at Wolnamsaji temple site in Gangjin. Komunhwa, 90, 25-49. (in Korean with English abstract)

Lee, J.S. and Park. J.S., 2014, Effect of changes on color characteristics by microstructural transformations of $\mathrm{Cu}-\mathrm{Sn}$ bronzes. Journal of Conservation Science, 30(4), 417-425. (in Korean with English abstract)

National Research Institute of Cultural Heritage, 2017, Scientific analysis on metal artifacts from Myanmar. 2640, 92-93. (in Korean)

Park, J.S. and Yu, J.E., 2004, On the manufacturing technology of the bronze artifacts excavated from the Icheon Seolbong fortress. Journal of Korean Cultural History, 21, 321-344.

Ryu, D.W. and Kim, S.K., 2011, A study of the manufacturing technique by scientific analysis and reproduction experiment of ancient silver objects from Neungnae-ri, Ganghwa island. Journal of Conservation Science, 27(1), 1-11. (in Korean with English abstract) 